\title{
Infection by Mycoplasma spp., feline immunodeficiency virus and feline leukemia virus in cats from an area endemic for visceral leishmaniasis
}

\author{
Mary Marcondes ${ }^{1 *}$ (D), Karina Y. Hirata', Juliana P. Vides ${ }^{1}$, Ludmila S. V. Sobrinho', Jaqueline S. Azevedo',
} Thállitha S. W. J. Vieira ${ }^{2}$ and Rafael F. C. Vieira ${ }^{2}$

\begin{abstract}
Background: Visceral leishmaniasis $(V L)$ has been increasingly recognized in cats living in areas endemic for the disease. Co-infection with Leishmania infantum and other infectious agents is well established in dogs. However, for cats, data on co-infections with $L$. infantum and other infectious agents are still sparse. The aim of this study was to identify the prevalence of vector-borne pathogens, Mycoplasma spp., feline immunodeficiency virus (FIV) and feline leukaemia virus (FeLV) in cats from an area endemic for VL in southeastern Brazil.

Results: Of the 90 cats, eight (8.9\%) were infected with Mycoplasma spp., five (5.5\%) were FIV- positive and one (1.1\%) was FeLV-positive. Co-infection with L. infantum and at least one other infectious agent was found in 9/50 (18.0\%; Cl: 8.6-31.4\%) cats. In Group 1 (cats infected naturally by L. infantum), 4/50 (8.0\%) cats were positive for FIV, 4/50 (8\%) for Mycoplasma spp. and 1/50 (2.0\%) was co-infected with FeLV and Mycoplasma spp. In Group 2 (cats non-infected with L. infantum), 2/40 (5.0\%) cats were infected with Mycoplasma spp. and 1/40 (2.5\%) was co-infected with FIV and Mycoplasma spp. All cats were negative for Ehrlichia spp., Babesia spp. and Anaplasma platys.

Conclusion: A low prevalence of co-infection in Leishmania-infected and non-infected cats was found. Co-infections with Leishmania and vector-borne diseases in cats are not common in this area endemic for VL in Brazil.
\end{abstract}

Keywords: Leishmania infantum, Ehrlichia spp., Babesia spp., Anaplasma platys, PCR

\section{Background}

Visceral leishmaniasis (VL) is a neglected zoonotic disease caused by Leishmania infantum, with dogs acting as the main reservoir for this protozoon pathogen. Visceral leishmaniasis has been recognized increasingly in cats living in areas endemic for the disease [1-4]. While infected cats are less frequently ill than dogs, probably due to a natural feline resistance, clinical disease has been associated with immunosuppressive coinfections with feline immunodeficiency virus (FIV) and feline leukemia virus (FeLV) [5].

\footnotetext{
* Correspondence: marcondes.mary@gmail.com

'São Paulo State University (Unesp), School of Veterinary Medicine,

Araçatuba, São Paulo, Brazil

Full list of author information is available at the end of the article
}

Although cats are exposed to arthropod parasites, their lifestyle habits may be a limiting factor for transmission of arthropod-borne pathogens, particularly those transmitted by ticks, compared with dogs [6]. In some regions of Brazil, cats are infested by ticks, such as Rhipicephalus sanguineus (sensu lato) [7-10], and thus may be infected with the pathogens they may transmit. Previous studies have found Brazilian free-roaming cats infected with Mycoplasma spp. and feline vector-borne pathogens (FVBPs) such as species of Babesia, Anaplasma or Ehrlichia $[11,12]$.

In areas endemic for VL, co-infections of $L$. infantum and other infectious agents are common in dogs [13-17]. Co-infection may potentiate disease pathogenesis and alter clinical manifestations, complicating diagnosis and treatment, and influencing prognosis [18]. Recent studies 
have been performed worldwide to characterize coinfections with $L$. infantum and other infectious agents, including other vector-borne pathogens (VBP), in cats [19-22]. In Brazil, data on co-infections are still sparse and limited to reports of co-infections with the major feline retroviruses, FIV and FeLV [19], Toxoplasma gondii [19, 23, 24] and Neospora caninum [24]. Therefore, the aim of this study was to identify co-infections with FVBPs, Mycoplasma spp., FIV and FeLV in Leishmania-infected and non-infected cats from an area endemic for VL in southeastern Brazil.

\section{Methods}

\section{Animals}

Ninety mixed-breed cats of different ages and sex, either presented to a veterinary teaching hospital (VTH) $(n=38$ cats) or living at two cat shelters $(n=52$ cats), in an area endemic for VL in Araçatuba, São Paulo, southeastern Brazil, were sampled between March 2014 and May 2015. Signalment and clinical data recorded included gender, age (sometimes estimated by assessment of dentition) and clinical signs reported by the cat owner or the person in charge of the cat shelter. A thorough physical examination was performed on each cat by a registered veterinary surgeon. The two shelters were sampled because they were known to have a high prevalence of $L$. infantum infection. According to the Leishmania infection status, based on blood and/or bone marrow polymerase chain reaction (PCR) testing, cats were subdivided into two groups: Group 1 (G1) included 50 cats infected naturally with $L$. infantum, and Group 2 (G2) included 40 cats known not to be infected with $L$. infantum. Cats were eligible for the study if: (i) they were at least 6 months-old; (ii) they had not been diagnosed or treated for leishmaniasis in the past; (iii) they had not received drugs with known antiLeishmania activity for the previous 6 months; and (iv) they had not received immune-modulating drugs for the previous 3 months.

\section{Sampling}

Blood samples and bone marrow aspirates were collected by a registered veterinary surgeon. Blood samples were collected by jugular venipuncture. One $\mathrm{ml}$ was placed into citrate tubes (BD Vacutainer ${ }^{\oplus}$, Becton Dickinson, Franklin Lakes, NJ, USA) for PCR analysis (Leishmania spp., Ehrlichia spp., Anaplasma platys, Mycoplasma spp. and Babesia spp.) and kept at $-80{ }^{\circ} \mathrm{C}$ until testing. Three milliliters were placed into tubes without anticoagulant and kept at room temperature $\left(25^{\circ} \mathrm{C}\right)$ until visible clot retraction; the samples were then centrifuged at $1500 \times g$ for 5 min, serum separated and kept at $-20{ }^{\circ} \mathrm{C}$ for serological studies. Bone marrow aspirates were collected for Leishmania PCR analysis from the iliac crest or femur of cats under anesthesia with a combination of ketamine
(5 mg/kg body weight; Quetamina ${ }^{\oplus}$ Vetnil, São Paulo, Brazil $)$ and midazolam $\left(0.3 \mathrm{mg} / \mathrm{kg}\right.$ body weight; Dormonid ${ }^{\circledR}$, Roche, Rio de Janeiro, Brazil). Samples were aspirated into heparinized syringes and then gently expelled into a sterile glass petri dish. Spicules were collected from the dish into sterile glass capillary tubes and then into citrate tubes (BD Vacutainer ${ }^{\bullet}$, Becton Dickinson, Franklin Lakes, NJ, USA) tubes for PCR analysis, and kept at $-80{ }^{\circ} \mathrm{C}$ until analyzed. Concurrently, one drop of the spicules collected from each sample was placed onto a glass microscope slide and a squash preparation was made. The slide was stained by Diff-Quick (Panótico Rápido ${ }^{\circ}$ Laborclin, São Paulo, Brazil) and evaluated cytologically by a veterinary clinical pathologist to confirm the presence and quality of bone marrow in the sample.

\section{Serological testing}

All serum samples were tested for FeLV p27 antigen and IgG antibodies against FIV, by a commercial enzymelinked immunosorbent assay (ELISA), rapid assay kit (SNAP ${ }^{\oplus}$ FIV Antibody/FeLV Antigen Combo Test: IDEXX Laboratories, Westbrook, ME, USA).

\section{DNA extraction}

After thawing at room temperature, $200 \mu \mathrm{l}$ of whole blood and bone marrow were subjected to DNA extraction using a commercial kit (QIAamp ${ }^{\mathrm{TM}}$ DNA Mini Kit Blood and Tissue, Qiagen, Valencia, CA, USA), according to the manufacturer's instructions. Negative control purifications using ultrapure water were performed in parallel to monitor cross-contamination in each batch of 30 samples. The concentration and purity of extracted DNA were assessed by spectrophotometry (ND-1000, Nano-Drop Technologies, Wilmington, DE, USA) by measuring the absorbance at 260 and $280 \mathrm{~nm}$, respectively. Thereafter, DNA aliquots were stored at $-20{ }^{\circ} \mathrm{C}$ until molecular testing.

\section{Detection of Leishmania DNA by real-time polymerase chain reaction}

The target Leishmania DNA for PCR amplification was a 116 base pair (bp) fragment in the constant region of the kinetoplast DNA minicircle, using primers described previously [25]. Briefly, the reaction was performed using a commercial mastermix with SYBR Green fluorophore (SYBRGreen JumpStart TaqReadMix S4438, Sigma-Aldrich, St Louis, MO, USA), $900 \mathrm{nM}$ of each primer and $5 \mu \mathrm{l}$ of DNA, in a final volume of $25 \mu \mathrm{l}$. Samples from blood and bone marrow (tested in triplicate) were placed into 96-well PCR plates and PCR amplification was carried out in a thermocycler (CFX96TM RealTime System, Bio-Rad, Hercules, CA, USA) using the following conditions: $94{ }^{\circ} \mathrm{C}$ for $2 \mathrm{~min}, 40$ cycles of $94{ }^{\circ} \mathrm{C}$ for $15 \mathrm{~s}$, followed by $60{ }^{\circ} \mathrm{C}$ for $1 \mathrm{~min}$, when fluorescence 
data were collected. To carry out melting curve analysis, the temperature was increased from $60{ }^{\circ} \mathrm{C}$ to $95{ }^{\circ} \mathrm{C}$, with an increment of $0.5{ }^{\circ} \mathrm{C}$ every $5 \mathrm{~s}$. The cycle threshold (Ct) value was calculated for each sample by determining the point at which the fluorescence exceeded the threshold limit. Each amplification run contained a positive control (DNA extracted from $1.6 \times 10^{4} \mathrm{~L}$. infantum promastigotes) in triplicate, to test the proper conditions of the reagents, and negative controls with ultrapure water in triplicate to monitor cross-contamination.

Detection of Ehrlichia spp., Anaplasma platys, Mycoplasma spp. and Babesia spp. by conventional polymerase chain reaction

A conventional PCR for the housekeeping gene glyceraldehyde-3-phosphate dehydrogenase (GAPDH) was performed to ensure successful DNA extraction, as previously described [26]. Samples were evaluated using conventional PCR with genus-specific primers targeting a portion of the $16 S$ rDNA gene of Ehrlichia spp. (344 bp) [27], A. platys (359 bp) [28] and Mycoplasma spp. (c.900 bp) $[29,30]$, and a portion of the $18 S$ rDNA gene of Babesia spp. (c.500 bp) [31]. For each PCR assay, DNA from dogs known to be infected with Ehrlichia spp., A. platys and Babesia spp., and cats known to be infected with Mycoplasma spp., and nuclease-free water were used as positive and negative controls, respectively. The amplified PCR products were subjected to gel electrophoresis in $1.5 \%$ agarose gels for $1 \mathrm{~h}$ at $100 \mathrm{~V}$, followed by SYBR safe staining $\left(6 \mu \mathrm{g} / \mathrm{ml}\right.$; SYBR ${ }^{\odot}$ Safe DNA Gel Stain, Invitrogen, CA, USA), and were viewed under a $312 \mathrm{~nm}$ UV light transilluminator.

\section{Sequencing}

Amplicons obtained randomly from eight Leishmaniapositive and all eight Mycoplasma spp.-positive samples were purified, evaluated by spectrophotometry for concentration and purity (Nanodrop ${ }^{\mathrm{TM}} 2000$ Spectrophotometer, Thermo Fisher Scientific, Wilmington, MA, USA), and sequenced in both directions by the Sanger method. Thereafter, sequences were subjected to BLASTn analysis [32] for determining the identity with the sequences deposited in the GenBank database. Sequencing was restricted to these 16 samples due to financial constraints.

\section{Statistical analysis}

Chi-square test was used to determine if age and sex were associated with infections, if Leishmania infection was associated with FIV, FeLV and Mycoplasma infection status and if FIV and Mycoplasma infections were associated. Fisher's exact test was used to determine if there was association between FeLV and Mycoplasma, and FIV and FeLV infections. Odds ratios (OR), 95\% confidence intervals and $P$-values were calculated, and results were considered significant when $P<0.05$. Data were compiled and analyzed by Epi Info ${ }^{\mathrm{Ts}}$ Software (version 7.1.5, CDC).

\section{Results}

A total of $28 / 90$ (31.1\%) male and 62/90 (68.9\%) female cats, all of mixed-breed, with ages ranging from 0.5 to 10 years (median 2 years), were included in the study. Among the Leishmania-infected cats (G1), 40/50 (80.0\%) were living in one of the shelters and 10/50 (20.0\%) were referred to the VTH, $17 / 50$ (34.0\%) were male and 33/50 (66.0\%) female, with ages ranging from 0.5 to 10 years (median 2 years). In G1, 20/50 (40.0\%, 95\% CI: 26.4$54.8 \%$ ) cats had evidence of clinical abnormalities on physical examination, including alopecia-hypotrichosis $(n=9$; $45.0 \%)$, weight loss $(n=7 ; 35.0 \%)$, lymph node enlargement ( $n=5 ; 25.0 \%)$, ulcerative skin lesions $(n=4 ; 20.0 \%)$, dehydration $(n=3 ; 15.0 \%)$, conjunctivitis $(n=2 ; 10.0 \%)$, mucosal pallor $(n=1 ; 5.0 \%)$, uveitis $(n=1 ; 5.0 \%)$, mucopurulent nasal discharge $(n=1 ; 5.0 \%)$, sneezing $(n=1 ; 5.0 \%)$, stomatitis $(n=1 ; 5.0 \%)$, vomiting $(n=1 ; 5.0 \%)$, diarrhea $(n=1$; $5.0 \%)$ and jaundice $(n=1 ; 5.0 \%)$. Among the non-infected cats (G2), 12/40 (30.0\%) were living in one of the shelters and $28 / 40(70.0 \%)$ were referred to the VTH, $11 / 40$ (27.5\%) were male and 29/50 (72.5\%) female, with ages ranging from 0.5 to 10 years (median 2.5 years). In G2, 12/40 (30.0\%, 95\% CI: 16.6-46.5\%) cats showed clinical signs including lymph node enlargement $(n=6$; $50.0 \%)$, weight loss $(n=4 ; 33.3 \%)$, ulcerative skin lesions $(n=3 ; 25.0 \%)$, ocular and/or nasal discharge $(n=3$; $25.0 \%)$, depression $(n=1 ; 8.3 \%)$, inappetence $(n=1 ; 8.3 \%)$, mucosal pallor $(n=1 ; 8.3 \%)$, oral mucosal ulceration $(n=1$; $8.3 \%)$, conjunctival hyperaemia $(n=1 ; 8.3 \%)$, and haematuria $(n=1 ; 8.3 \%)$,while the other $28 / 40$ (70.0\%, 95\% CI: $53.5-83.4 \%)$ were healthy and had been referred to the VTH for neutering.

Cytological evaluation confirmed that all samples were of bone marrow, and in seven Leishmania-infected cats (14.0\%), all presenting with clinical signs, Leishmania spp. amastigotes were observed in bone marrow cytology. The GAPDH gene was consistently amplified from all samples subjected to PCR. In 58.0\% $(n=29)$ of the infected cats Leishmania DNA was amplified from both bone marrow and blood. In 28.0\% $(n=14)$ and $14.0 \%(n=7)$ of the cats, Leishmania DNA was amplified only from bone marrow and blood, respectively. Of the 90 cats, eight (8.9\%, 95\% CI: 3.9-16.7\%) were infected with Mycoplasma spp., five (5.5\%, 95\% CI: 1.8-12.5\%) were FIV-positive and one (1.1\%, 95\% CI: 0.03-6.0\%) was FeLV-positive. Co-infection with Leishmania and at least one other infectious agent was found in 9/50 (18.0\%, 95\% CI: 8.6-31.4\%) cats. In G1 4/50 (8.0\%, 95\% CI: $2.2-19.2 \%)$ cats were positive for FIV, $4 / 50$ (8.0\%, 95\% CI: 2.2-19.2\%) for Mycoplasma spp. and 
1/50 (2.0\%, 95\% CI: 0.05-10.6\%) was co-infected with FeLV and Mycoplasma spp. The later animal was a 4 year-old male cat co-infected with FeLV and "Candidatus Mycoplasma haemominutum". The cat was referred to the VTH with weight loss, pale mucous membranes with packed cell volume (PCV) of $20 \%$, dehydration, sneezing and serous mucopurulent nasal discharge, which led to a suspicion of feline herpesvirus-1 (FHV-1) infection; an ulcerative lesion at the base of the left pinna suggesting a neoplastic process, that was further not confirmed, and flea infestation. The cat did not return for the next consultation since it disappeared from the house on the next day after the visit to the hospital.

In G2, 2/40 (5.0\%, 95\% CI: 0.6-16.9\%) cats were infected with Mycoplasma spp. and 1/40 (2.5\%, 95\% CI: 0.06-13.2\%) was co-infected with FIV and Mycoplasma spp. All cats were negative for Ehrlichia spp., Babesia spp. and A. platys.

Association between sex and infection by Leishmania $\left(\chi^{2}=0.4381, d f=1, P=0.5081\right)$, FIV $\left(\chi^{2}=2.0615, d f=1\right.$, $P=0.1511)$ and FeLV $\left(\chi^{2}=2.2392, d f=1, P=0.1346\right)$ was not observed. Male cats were more likely to be infected with Mycoplasma spp. $\left(\chi^{2}=7.8916, d f=1, P=0.0050\right)$. Association between positivity for Leishmania and FIV $\left(\chi^{2}=1.2812, d f=1, P=0.2577\right)$, Leishmania and FeLV $\left(\chi^{2}=0.8090, d f=1, P=0.3684\right)$, Leishmania and Mycoplasma spp. $\left(\chi^{2}=0.1715, d f=1, P=0.6788\right)$, FIV and FeLV $(P=1.0000$, OR: unable to calculate), FIV and Mycoplasma spp. $\left(\chi^{2}=0.8070, d f=1, P=0.3690\right)$, and FeLV and Mycoplasma spp. $(P=0.0889$, OR: undefined $)$ was not observed. The prevalence of infectious pathogens in Leishmania-infected and non-infected cats for each variable evaluated is summarized in Table 1.

Nucleotide sequences from eight Leishmania-infected cats had $\geq 99 \%$ identity with multiple $L$. infantum kDNA gene sequences deposited in GenBank (KJ417491, AB678348, EU437407, EU437406, EU437405). Four out of the eight Mycoplasma-positive samples sequenced showed $\geq 98 \%$ identity with multiple " $\mathrm{Ca}$. M. haemominutum" $16 \mathrm{~S}$ rDNA gene sequences deposited in GenBank (accession nos. KU852585, EU839983, AY150981), two and one sequences showed $\geq 99 \%$ identity with Mycoplasma haemofelis (accession nos. KM 275241, KM275239), and "Candidatus Mycoplasma turicensis" (accession no. KM275263), respectively. Multiple attempts to amplify the $16 S$ rDNA from the remaining Mycoplasma-positive sample were unsuccessful.

In G1, two cats were co-infected with "Ca. M. haemominutum", two with Mycoplasma haemofelis and one with "Ca. M. turicensis". In G2, two cats were infected with "Ca. M. haemominutum" and in one cat Mycoplasma DNA sequencing was unsuccessful.

\section{Discussion}

Feline vector-borne diseases (FVBDs) have been less investigated than canine vector-borne diseases (CVBDs) in part because of difficulties in making a diagnosis of FVBD since there are fewer commercially available diagnostic tests. Additionally, the research community that focuses on FVBDs is smaller than that which studies CVBDs. Finally, it is suggested that diseases in cats are diagnosed less frequently, since cats are not taken for

Table 1 Prevalence of infectious pathogens in Leishmania-infected and non-infected cats from an area endemic for visceral leishmaniasis in Brazil

\begin{tabular}{|c|c|c|c|c|c|c|}
\hline & \multicolumn{2}{|l|}{ FIV } & \multicolumn{2}{|l|}{ FeLV } & \multicolumn{2}{|c|}{ Mycoplasma spp. } \\
\hline & $+/ n(\%)$ & $P$-value & $+/ n(\%)$ & $P$-value & $+/ n(\%)$ & $P$-value \\
\hline \multicolumn{7}{|c|}{ Cats infected with Leishmania (G1) } \\
\hline \multicolumn{7}{|l|}{ Sex } \\
\hline Male & 2/18 (11.1) & 0.6123 & $1 / 18(5.0)$ & 0.3600 & $4 / 18(22.2)$ & 0.0500 \\
\hline Female & 2/32 (6.2) & & $0 / 32(0)$ & & $1 / 32(3.1)$ & \\
\hline \multicolumn{7}{|l|}{ Age } \\
\hline$>1$ year & $4 / 32(12.5)$ & 0.1178 & $1 / 32(3.0)$ & 1.000 & $5 / 32(15.6)$ & 0.0770 \\
\hline$\leq 1$ year & 0/18 (0) & & 0/18 (0) & & $0 / 18(0)$ & \\
\hline \multicolumn{7}{|c|}{ Cats non-infected with Leishmania (G2) } \\
\hline \multicolumn{7}{|l|}{ Sex } \\
\hline Male & $1 / 10(10.0)$ & 0.2500 & $0 / 10(0)$ & na & $2 / 10(20.0)$ & 0.1480 \\
\hline Female & $0 / 30(0)$ & & $0 / 30(0)$ & & $1 / 30(3.3)$ & \\
\hline \multicolumn{7}{|l|}{ Age } \\
\hline$>1$ year & $1 / 20(5.0)$ & 1.000 & $0 / 20(0)$ & na & $3 / 20(15.0)$ & 0.2307 \\
\hline$\leq 1$ year & 0/20 (0) & & $0 / 20(0)$ & & $0 / 20(0)$ & \\
\hline
\end{tabular}

Abbreviations: FIV feline immunodeficiency vírus, FeLV feline leukaemia virus, + number of positive cats, $n$ total number, na not applicable 
veterinary consultation as often as dogs [6]. Even with the introduction of molecular techniques, since prevalence data for FVBDs are scarce, veterinarians sometimes may not consider the possibility of occurrence of those diseases [33]. Although some studies have investigated FVBD prevalence among cat populations worldwide [20-22, 34-37], a limited number of such studies have been reported from Brazil [11, 12, 36, 38], except for investigations of feline leishmaniasis [4, 19, 24, 39-43].

The present study is the first to evaluate co-infections in Leishmania-infected and non-infected cats from an area endemic for VL in Brazil. In the same area, a previous study in dogs reported a Leishmania seroprevalence of $48.0 \%$ [44]. Additionally, dogs from the same endemic area for VL have been shown to be co-infected with Leishmania and E. canis, B. vogeli, T. gondii [14] and N. caninum [44].

The cat population studied herein was a convenience sample. Sampling was performed on animals attending a VTH or residing in a local cat shelter environment. However, the cat population provided a good spectrum of healthy and clinically ill animals with two different lifestyles.

In order to increase the sensitivity of detection of Leishmania DNA, both blood and bone marrow samples were collected. PCR on bone marrow has been reported to be more sensitive than using whole blood for the diagnosis of canine leishmaniasis [45]. In a previous study, Leishmania DNA was amplified from bone marrow, whole blood and in both samples from 22.0\%, $22.0 \%$ and $7.32 \%$ of the infected cats, respectively [46]. Conversely, in the present study, bone marrow was the more sensitive sample for the diagnosis of infection ( $n=43$ cats; $86.0 \%)$ compared with blood ( $n=36$ cats; $72.0 \%)$. If only whole blood had been used to detect Leishmania DNA, $10.0 \%$ of the cats would have had a false-negative PCR result.

In the present study, $18.0 \%$ of Leishmania-infected cats were co-infected with at least one infectious agent. Although Leishmania co-infection is commonly related to infection with FIV $[19,47,48]$ and FeLV $[48,49]$, the cats studied herein were also co-infected with feline hemoplasmas, as previously observed in cats from Cyprus [21].

The prevalence of FIV infection in the present study was 5.5\%. Co-infection with Leishmania and FIV was observed in $8.0 \%$ cats, while $2.5 \%$ of the non-infected cats were FIVpositive. Three of the Leishmania-FIV co-infected cats had skin lesions similar to those previously observed by Vides et al. [4] in cats with VL. In general, the animals were in good body condition, without evidence of other systemic disease or clinical signs of FIV infection. In the same area as the present study, a previous study has found an association between co-infection with Leishmania spp. and FIV, suggesting that cats living in areas endemic for VL are significantly more likely to be co-infected with FIV [19].

Previous studies have found an association between Leishmania and FeLV infection [47]. The low number of FeLV-infected cats evaluated in the present study has impaired statistical analysis. A previous study in the same area endemic for VL reported a FeLV prevalence of $0.33 \%$, although co-infection with Leishmania and FeLV was not observed [19]. The only cat co-infected with Leishmania and FeLV in the present study, was also infected with "Ca. M. haemominutum". The cat was referred to the VTH due to an upper respiratory tract infection, probably caused by FHV-1 and feline calicivirus (FCV), associated with FeLV infection [50]. The ulcerative lesion on the pinna was similar to those observed previously in cats with VL [4]. While hematological abnormalities in cats infected with " $\mathrm{Ca}$. M. haemominutum" may be minor or absent, co-infection with " $\mathrm{Ca}$. M. haemominutum" and FeLV can cause severe anaemia [51], which could explain the low PCV observed in the cat. Although there are few reports of cats co-infected with Leishmania and two or more infectious agents [19, 52], to the authors' best knowledge the present study represents the first report of a cat co-infected with Leishmania, FeLV and "Ca. M. haemominutum".

Hemoplasma infection is a relatively common finding in cats worldwide [21, 53-55], and these infections are widely recognized in Brazil [11, 56-58]. In the present study, 8.9\% of the cats were positive for Mycoplasma spp., with " $\mathrm{Ca}$. M. haemominutum" being the most prevalent species (50.0\%), similar to previous studies [11, 21, 58-60]. It is important to note that a hemoplasma screening method was used herein, and therefore, co-infections by multiple hemoplasma species may have been missed. Global prevalence data on feline hemoplasmas range from $6.5 \%$ to $38.5 \%$ [11, 53-55, 57, 58, 60]. Differences in hemoplasma prevalence may be attributed to the sensitivity of the assay (i.e. conventional PCR vs quantitative PCR), the population studied, the geographical location and sampling methods (i.e. convenience non-randomized samples vs nonconvenience randomized samples).

Impaired immunocompetence (e.g. caused by immunosuppressive FIV and/or FeLV co-infection) has been associated historically with enhanced pathogenicity of Mycoplasma spp. [54, 55, 61]. In Brazil, a previous study has found an association between co-infection with "Ca. M. haemominutum" and FIV [62]. Herein, besides the cat that was co-infected with Leishmania, FeLV and "Ca. M. haemominutum", one cat was co-infected with FIV and "Ca. M. haemominutum", one with Leishmania and "Ca. M. haemominutum", and one single infected with " $\mathrm{Ca}$. M. haemominutum". Except for the first, the other three cats had a red blood cell (RBC) count within the normal range (data not shown). Despite 
most infections with " $\mathrm{Ca}$. M. haemominutum" being chronic and not associated with anaemia [63, 64], previous studies have reported cats with haemolytic anaemia where no apparent causative agent other than " $\mathrm{Ca}$. M. haemominutum" was identified, although primary immune-mediated haemolytic anaemia may have been the underlying cause in some or all of those cats [64]. To the best of the authors' knowledge, this is the first study documenting co-infection with L. infantum and Mycoplasma spp. in cats from South America. Further studies should be conducted to better elucidate the association between $L$. infantum and feline hemoplasmas.

Recent studies have focused on providing data on FVBDs [20, 22, 34, 35, 37]. A few have also evaluated Mycoplasma spp. infection [21,37] with L. infantum-infected cats being seven times more likely to be infected with "Ca. M. turiscensis" [21]. Feline hemoplasma infection has been associated previously with male sex [64], in agreement with the present study, where male cats were eight times more likely to be infected with $\mathrm{Myco}$ plasma spp. $(P=0.0050)$.

All of the present cats were negative for the tick-borne pathogens (TBPs) species Ehrlichia and Babesia, similar to previous studies [22]. There are many hypotheses to explain why cats may be less prone to arthropod-borne diseases, including their grooming behavior that could remove ticks before pathogen transmission, and a natural, genetically controlled immunological resistance to arthropods and the microorganisms they may transmit [6].

Previous studies in cats have reported low prevalence rates for some TBPs [20, 36, 37]. Molecular detection followed by sequencing studies in Brazilian cats revealed a low prevalence of infection by E. canis [65, 66], A. platys [67] and closely related species [12, 68, 69]. In contrast, a significant molecular prevalence of Babesia spp. infection was found in Brazilian cats [11, 12], in agreement with previous studies on cats in Portugal [20]. Rhipicephalus sanguineus (s.l.) ticks, the main vector of these TBPs, are widely distributed in Brazil [70]. Although reports of infestation by this tick species in cats are rare [7-10], $R$. sanguineus (s.l.), has been described as parasitizing cats [71]. In the present study, none of the animals were infested by ticks at the time of clinical examination, which may have contributed to the TBP negative status.

\section{Conclusions}

A low prevalence of co-infection with FVBDs in either Leishmania-infected and non-infected cats was found in this study. Infection with TBPs are not common in cats in this area endemic for VL in Brazil. To our knowledge, this is the first study documenting co-infection with $L$. infantum and Mycoplasma spp. in cats from South America.

\section{Abbreviations}

CVBD: canine vector-borne diseases; ELISA: enzyme-linked immunosorbent assay; FCV: feline calicivirus; FeLV: feline leukemia virus; FHV-1: feline herpesvirus-1; FIV: feline immunodeficiency virus; FVBD: feline vector-borne diseases; FVBP: feline vector-borne pathogens; GAPDH: glyceraldehyde-3phosphate dehydrogenase; OR: odds ratio; PCR: polymerase chain reaction; PCV: packed cell volume; RBCs: red blood cells; TBP: tick-borne pathogen; VBP: vector-borne pathogens; VL: visceral leishmaniasis; VTH: veterinary teaching hospital

\section{Acknowledgements}

Publication of this paper has been sponsored by Bayer Animal Health in the framework of the 13th CVBD World Forum Symposium. The authors are grateful to Emeritus Professor Michael J. Day for revising the English language of the article.

Funding

Not applicable.

\section{Availability of data and materials}

The datasets used and/or analyzed during the current study are available from the corresponding author upon reasonable request.

\section{Authors' contributions}

MM, TSWJV and RFCV conceived the research study. KYH, JPV, LSVS and JSA collected the samples. KYH, JPV, LSVS, JSA and TSWJV performed the laboratory techniques with the collaboration of MM and RFCV. TSWJV and MM performed statistical analysis. MM, TSWJV and RFCV analyzed data and wrote the manuscript. All authors read and approved the final manuscript.

\section{Ethics approval and consent to participate}

The study was approved by the Ethics Committee in Animal Experimentation and Animal Welfare of São Paulo State University (UNESP) Araçatuba (protocol number 2008-005698), and conducted according to the ethical principles of animal experimentation, adopted by the Brazilian College of Animal Experimentation. Samples were collected after written consent from the person in charge of the cat shelter or the owner of the cat.

\section{Consent for publication}

Not applicable.

\section{Competing interests}

The authors declare that they have no competing interests.

\section{Publisher's Note}

Springer Nature remains neutral with regard to jurisdictional claims in published maps and institutional affiliations.

\section{Author details}

'São Paulo State University (Unesp), School of Veterinary Medicine, Araçatuba, São Paulo, Brazil. ²Department of Veterinary Medicine, Universidade Federal do Paraná, Curitiba, Paraná, Brazil.

Received: 16 November 2017 Accepted: 15 February 2018 Published online: 20 March 2018

\section{References}

1. Martín-Sánchez J, Acedo C, Muños-Pérez M, Pesson B, Marchal O, Morillas-Márquez F. Infection by Leishmania infantum in cats: epidemiological study in Spain. Vet Parasitol. 2007;30:267-73.

2. Solano-Gallego L, Rodríguez-Cortés A, Iniesta L, Quintana J, Pastor J, Espada $Y$, et al. Cross-sectional serosurvey of feline leishmaniasis in ecoregions around the northwestern Mediterranean. Am J Trop Med Hyg. 2007;76:676-80.

3. Maia C, Gomes J, Cristóvão J, Nunes M, Martins A, Rebêlo E, et al. Feline Leishmania infection in a canine leishmaniasis endemic region. Portugal Vet Parasitol. 2010;174:336-40.

4. Vides JP, Schawardt TF, Sobrinho LSV, Marinho M, Laurenti MD, Biondo AW, et al. Leishmania chagasi infection in cats with dermatologic lesions from an endemic area of visceral leishmaniasis in Brazil. Vet Parasitol. 2011;178:22-8. 
5. Pennisi MG, Cardoso L, Baneth G, Bourdeau P, Koutinas A, Miró G, et al. LeishVet update and recommendations on feline leishmaniosis. Parasit Vectors. 2015;8:302.

6. Day MJ. Cats are not small dogs: is there an immunological explanation for why cats are less affected by arthropod-borne disease than dogs? Parasit Vectors. 2016:9:507.

7. Aragão HB. Ixodidas brasileiros e de alguns países limítrofes. Mem Inst Oswaldo Cruz. 1936:31:759-844.

8. Mendes-de-Almeida F, Labarthe N, Guerrero J, Faria MC, Branco AS, Pereira CD, et al. Follow-up of the health conditions of an urban colony of free-roaming cats (Felis catus Linnaeus, 1758) in the city of Rio de Janeiro. Brazil Vet Parasitol. 2007;147:9-15.

9. Mendes-de-Almeida F, Crissiuma AL, Gershony LC, Willi LM, Paiva JP, Guerrero J, et al. Characterization of ectoparasites in an urban cat (Felis catus Linnaeus, 1758) population of Rio de Janeiro. Brazil Parasitol Res. 2011;108:1431-5.

10. Ferreira DRA, Alves LC, Faustino MAG. Ectoparasitos de Felis catus domesticus (Linnaeus, 1758) na cidade de João Pessoa, Paraíba. Brasil Biotemas. 2010;23:43-50.

11. André MR, Denardi NCB, Sousa KCM, Gonçalves LR, Henrique PC, Ontivero CRGR, et al. Arthropod-borne pathogens circulating in free-roaming domestic cats in a zoo environment in Brazil. Ticks Tick Borne Dis. 2014;5:545-51.

12. André MR, Herrera HM, Fernandes SJ, Sousa KCM, Gonçalves LR, Domingos IH, et al. Tick-borne agents in domesticated and stray cats from the city of Campo Grande, state of Mato Grosso do Sul, midwestern Brazil. Ticks Tick Borne Dis. 2015;6:779-86.

13. Mylonakis ME, Soubasis N, Balakrishnan N, Theodorou K, Kasabalis D, Saridomichelakis M, et al. Molecular identification of Bartonella species in dogs with leishmaniosis (Leishmania infantum) with or without cytological evidence of arthritis. Vet Microbiol. 2014;174:272-5.

14. Cardinot CB, Silva JE, Yamatogi RS, Nunes CM, Biondo AW, Vieira RF, et al. Detection of Ehrlichia canis, Babesia vogeli, and Toxoplasma gondii DNA in the brain of dogs naturally infected with Leishmania infantum. J Parasitol. 2016;102:275-9.

15. Maia C, Altet L, Serrano L, Cristóvão JM, Tabar MD, Francino O, et al. Molecular detection of Leishmania infantum, filariae and Wolbachia spp. in dogs from southern Portugal. Parasit Vectors. 2016;9:170.

16. Morgado FN, Cavalcanti AD, Miranda LH, O'Dwyer LH, Silva MR, Menezes RC, et al. Hepatozoon canis and Leishmania spp. coinfection in dogs diagnosed with visceral leishmaniasis. Rev Bras Parasitol Vet. 2016:25:450-8.

17. Vascellari M, Ravagnan S, Carminato A, Cazzin S, Carli E, Da Rold G, et al. Exposure to vector-borne pathogens in candidate blood donor and free-roaming dogs of northeast Italy. Parasit Vectors. 2016;9:369.

18. De Tommasi AS, Otranto D, Dantas-Torres F, Capelli G, Breitschwerdt EB, de Caprariis D. Are vector-borne pathogen co-infections complicating the clinical presentation in dogs? Parasit Vectors. 2013;6:97.

19. Sobrinho LS, Rossi CN, Vides JP, Braga ET, Gomes AA, de Lima VM, et al. Coinfection of Leishmania chagasi with Toxoplasma gondii, feline immunodeficiency virus (FIV) and feline leukemia virus (FeLV) in cats from an endemic area of zoonotic visceral leishmaniasis. Vet Parasitol. 2012;187:302-6.

20. Vilhena H, Martinez-Díaz VL, Cardoso L, Vieira L, Altet L, Francino O, et al. Feline vector-borne pathogens in the north and centre of Portugal. Parasit Vectors. 2013;6:99.

21. Attipa C, Papasouliotis K, Solano-Gallego L, Baneth G, Nachum-Biala Y, Sarvani $E$, et al. Prevalence study and risk factor analysis of selected bacterial, protozoal and viral, including vector-borne, pathogens in cats from Cyprus. Parasit Vectors. 2017;10:130.

22. Otranto D, Napoli E, Latrofa MS, Annoscia G, Tarallo VD, Greco G, et al. Feline and canine leishmaniosis and other vector-borne diseases in the Aeolian Islands: pathogen and vector circulation in a confined environment. Vet Parasitol. 2017;236:144-51.

23. Braga AR, Corrêa AP, Camossi LG, Silva RC, Langoni H, Lucheis SB. Coinfection by Toxoplasma gondii and Leishmania spp. in domestic cats (Felis catus) in state of Mato Grosso do Sul. Rev Soc Bras Med Trop. 2014;47:796-7.

24. Sousa KC, Herrera HM, Domingos IH, Campos JB, Santos IM, Neves HH, et al. Serological detection of Toxoplasma gondii, Leishmania infantum and Neospora caninum in cats from an area endemic for leishmaniasis in Brazil. Rev Bras Parasitol Vet. 2014;23:449-55.

25. Ranasinghe S, Rogers ME, Hamilton JGC, Bates PA, Maingon RDC. A real-time PCR assay to estimate Leishmania chagasi load in its natural sand fly vector Lutzomyia longipalpis. Trans R Soc Trop Med Hyg. 2008;102:875-82.
26. Birkenheuer AJ, Levy MG, Breitschwerdt EB. Development and evaluation of a seminested PCR for detection and differentiation of Babesia gibsoni (Asian genotype) and B. canis DNA in canine blood samples. J Clin Microbiol. 2003:41:4172-7.

27. Inokuma H, Raoult D, Brouqui P. Detection of Ehrlichia platys DNA in brown dog ticks (Rhipicephalus sanguineus) in Okinawa Island Japan. J Clin Microbiol. 2000;38:4219-21.

28. Murphy GL, Ewing SA, Whitworth LC, Fox JC, Kocan AA. A molecular and serologic survey of Ehrlichia canis, E. chaffeensis, and E. ewingii in dogs and ticks from Oklahoma. Vet Parasitol. 1998;79:325-39.

29. Hoelzle K, Winkler M, Kramer MM, Wittenbrink MM, Dieckmann SM, Hoelzle LE. Detection of "Candidatus Mycoplasma haemobos" in cattle with anaemia. Vet J. 2011;187:408-10.

30. Machado CAL, Vidotto O, Conrado FO, Santos NJR, Valente JDM, Barbosa IC, et al. Mycoplasma ovis infection in goat farms from northeastern Brazil. Comp Immunol Microbiol Infect Dis. 2017;55:1-5.

31. Soares JF, Girotto A, Brandão PE, Da Silva AS, França RT, Lopes STA, et al. Detection and molecular characterization of a canine piroplasm from Brazil. Vet Parasitol. 2011;180:203-8.

32. Altschul SF, Gish W, Miller W, Myers EW, Lipman DJ. Basic local alignment search tool. J Mol Biol. 1990;215:403-10.

33. Hegarty BC, Qurollo BA, Thomas B, Park K, Chandrashekar R, Beall MJ, et al. Serological and molecular analysis of feline vector-borne anaplasmosis and ehrlichiosis using species-specific peptides and PCR. Parasit Vectors. 2015;8:320.

34. Solano-Gallego L, Hegarty B, Espada Y, Llull J, Breitschwerdt E. Serological and molecular evidence of exposure to arthropod-borne organisms in cats from northeastern Spain. Vet Microbiol. 2006;118:274-7.

35. Tabar MD, Altet L, Francino O, Sánchez A, Ferrer L, Roura X. Vector-borne infections in cats: molecular study in Barcelona area (Spain). Vet Parasitol. 2008:151:332-6.

36. Malheiros J, Costa MM. Do Amaral RB, de Sousa KCM, André MR, Machado RZ, et al. Identification of vector-borne pathogens in dogs and cats from southern Brazil. Ticks Tick Borne Dis. 2016;7:893-900.

37. Alho AM, Lima C, Latrofa MS, Colella V, Ravagnan S, Capelli G, et al. Molecular detection of vector-borne pathogens in dogs and cats from Qatar. Parasit Vectors. 2017;10:298.

38. Braga ÍA, de Souza Ramos DG, Marcili A, Melo ALT, Taques IIGG, Amude AM, et al. Molecular detection of tick-borne protozoan parasites in a population of domestic cats in midwestern Brazil. Ticks Tick Borne Dis. 2016;7:1004-9.

39. Bresciani KDS, Serrano ACM, de Matos LVS, Savani ESMM, D'Auria SRN, Perri SHV, et al. Ocorrência de Leishmania spp. em felinos do município de Araçatuba, SP. Rev Bras Parasitol Vet. 2010;19:127-9.

40. Coelho WMD, Richini-Pereira VB, Langoni H, Bresciani KDS. Molecular detection of Leishmania sp. in cats (Felis catus) from Andradina municipality, São Paulo State, Brazil. Vet Parasitol. 2011;176:281-2.

41. Cardia DF, Camossi LG, Neto LS. Langoni H, Bresciani KD. Prevalence of Toxoplasma gondii and Leishmania spp. infection in cats from Brazil. Vet Parasitol. 2013;197:634-7.

42. Baldani-Peruca LC, Lucheis SB, Tome RO, Richini-Pereira VB, Troncarelli MZ, da Silva RC, et al. Leishmania infantum (syn. chagasi) infection in cats from a brazilian southeastern endemic area for canine and human leishmaniasis. Vet Zootec. 2017;24:216-25.

43. Mendonça IL, Batista JF, Ribeiro IMM, Rocha FSB, Silva SO, Melo MN. Leishmania infantum in domestic cats from the municipality of Teresina, state of Piauí. Brazil Parasitol Open. 2017;3:e1.

44. Gennari SM, Franco WAC, Feitosa MM, Ikeda FA, de Lima VMF, Amaku M. Presence of anti-Neospora caninum and Toxoplasma gondii antibodies in dogs with visceral leishmaniosis from the region of Araçatuba, São Paulo, Brazil. Braz J Vet Res Anim Sci. 2006;43:613-9.

45. Solano-Gallego L, Koutinas A, Miró G, Cardoso L, Pennisi MG, Ferrer L, et al. Directions for the diagnosis, clinical staging, treatment and prevention of canine leishmaniosis. Vet Parasitol. 2009;165(1-2):1-18.

46. Chatzis MK, Andreadou M, Leontides L, Kasabalis D, Mylonakis M, Koutinas AF, et al. Cytological and molecular detection of Leishmania infantum in different tissues of clinically normal and sick cats. Vet Parasitol. 2014;202(3-4):217-25.

47. Pennisi MG, Venza M, Reale S, Vitale F, Lo Giudice S. Case report of leishmaniasis in four cats. Vet Res Commun. 2004;28(Suppl 1):363-6.

48. Grevot A, Jaussaud Hugues P, Marty P, Pratlong F, Ozon C, Haas P, et al. Leishmaniosis due to Leishmania infantum in a FIV and FeLV positive cat with a squamous cell carcinoma diagnosed with histological, serological and isoenzymatic methods. Parasite. 2005;12:271-5. 
49. Sherry K, Miró G, Trotta M, Miranda C, Montoya A, Espinosa C, et al. A serological and molecular study of Leishmania infantum infection in cats from the island of Ibiza (Spain). Vector Borne Zoonotic Dis. 2011;11:239-45.

50. Hartmann K. Clinical aspects of feline immunodeficiency and feline leukemia virus infection. Vet Immunol Immunopathol. 2011;143:190-201.

51. Foley JE, Pedersen NC. 'Candidatus Mycoplasma haemominutum', a lowvirulence epierythrocytic parasite of cats. Int I Syst Evol Microbiol. 2001; 51(3):815-7.

52. Spada E, Canzi I, Baggiani L, Perego R, Vitale F, Migliazzo A, et al. Prevalence of Leishmania infantum and co-infections in stray cats in northern Italy. Comp Immunol Microbiol Infect Dis. 2016;45:53-8.

53. Lobetti RG, Tasker S. Diagnosis of feline haemoplasma infection using a real-time PCR assay. J S Afr Vet Assoc. 2004;75:94-9.

54. Willi B, Boretti FS, Baumgartner C, Tasker S, Wenger B, Cattori V, et al. Prevalence, risk factor analysis, and follow-up of infections caused by three feline hemoplasma species in cats in Switzerland. J Clin Microbiol. 2006:44:961-9.

55. Jenkins KS, Dittmer KE, Marshall JC, Tasker S. Prevalence and risk factor analysis of feline haemoplasma infection in New Zealand domestic cats using a real-time PCR assay. J Feline Med Surg. 2013;15:1063-9.

56. Biondo AW, Dos Santos AP, Guimarães AM, Vieira RF, Vidotto O, Macieira Dde B, et al. A review of the occurrence of hemoplasmas (hemotrophic mycoplasmas) in Brazil. Rev Bras Parasitol Vet. 2009;18:1-7.

57. De Bortoli CP, André MR, Seki MC, Pinto AA, Machado Sde T, Machado RZ Detection of hemoplasma and Bartonella species and co-infection with retroviruses in cats subjected to a spaying/neutering program in Jaboticabal, SP, Brazil. Rev Bras Parasitol Vet. 2012;21:219-23.

58. Santos AP, Conrado Fde O, Messick JB, Biondo AW, Oliveira ST, Guimaraes AM, et al. Hemoplasma prevalence and hematological abnormalities associated with infection in three different cat populations from southern Brazil. Rev Bras Parasitol Vet. 2014;23:428-34.

59. Weingart C, Tasker S, Kohn B. Infection with haemoplasma species in 22 cats with anaemia. J Feline Med Surg. 2016;18:129-36.

60. Bergmann M, Englert T, Stuetzer B, Hawley JR, Lappin MR, Hartmann K. Risk factors of different hemoplasma species infections in cats. BMC Vet Res. 2017;13:52.

61. George JW, Rideout BA, Griffey SM, Pedersen NC. Effect of preexisting FeLV infection or FeLV and feline immunodeficiency virus coinfection on pathogenicity of the small variant of Haemobartonella felis in cats. Am J Vet Res. 2002;63:1172-8.

62. Macieira DB, de Menezes RC, Damico CB, Almosny NR, McLane HL, Daggy JK, et al. Prevalence and risk factors for hemoplasmas in domestic cats naturally infected with feline immunodeficiency virus and/or feline leukemia virus in Rio de Janeiro. Brazil J Feline Med Surg. 2008;10:120-9.

63. Foley JE, Harrus S, Poland A, Chomel B, Pedersen NC. Molecular, clinical, and pathologic comparison of two distinct strains of Haemobartonella felis in domestic cats. Am J Vet Res. 1998;59:1581-8.

64. Sykes JE. Feline hemotropic mycoplasmas. Vet Clin Small Anim. 2010;40:1157-70.

65. De Oliveira LS, Mourão LC, Oliveira KA, da Matta AM, De Oliveira AC, de Almeida MR, et al. Molecular detection of Ehrlichia canis in cats in Brazil. Clin Microbiol Infect. 2009;15:53-4.

66. Braga IA, Santos LGF, Ramos DGS, Melo ALT, Mestre GLC, Aguiar DM. Detection of Ehrlichia canis in domestic cats in the central-western region of Brazil. Braz J Microbiol. 2014;45(2):641-5.

67. Lima ML, Soares PT, Ramos CA, Araújo FR, Ramos RA, Souza II, et al. Molecular detection of Anaplasma platys in a naturally-infected cat in Brazil. Braz J Microbiol. 2010;41:381-5.

68. Correa ES, Paludo GR, Scalon MC, Machado JA, Lima ACQ, Pinto ATB, et al. Investigação molecular de Ehrlichia spp. e Anaplasma platys em felinos domésticos: alterações clínicas, hematológicas e bioquímicas. Pesqui Vet Bras. 2011;31:899-909.

69. Braga MSCO, André MR, Freschi CR, Teixeira MCA, Machado RZ. Molecular and serological detection of Ehrlichia spp. in cats on São Luís Island, Maranhão, Brazil. Rev Bras Parasitol Vet. 2012;21:37-41.

70. Moraes-Filho J, Marcili A, Nieri-Bastos FA, Richtzenhain LJ, Labruna MB Genetic analysis of ticks belonging to the Rhipicephalus sanguineus group in Latin America. Acta Trop. 2011;117:51-5.

71. Shaw SE, Birtles RJ, Day MJ. Arthropod-transmitted infectious diseases of cats. J Feline Med Surg. 2001;3:193-209.

\section{Submit your next manuscript to BioMed Central and we will help you at every step:}

- We accept pre-submission inquiries

- Our selector tool helps you to find the most relevant journal

- We provide round the clock customer support

- Convenient online submission

- Thorough peer review

- Inclusion in PubMed and all major indexing services

- Maximum visibility for your research

Submit your manuscript at www.biomedcentral.com/submit
Biomed Central 